\title{
Kansei Engineering for Quantification of Indigenous Knowledges in Agro-industrial Technology
}

\author{
Mirwan Ushada ${ }^{*}, 1$ and Tsuyoshi Okayama ${ }^{2}$ \\ ${ }^{1}$ Department of Agro-industrial Technology, Faculty of Agricultural Technology \\ Universitas Gadjah Mada, Jl. Flora No.1 Bulaksumur 55281, Indonesia. \\ ${ }^{2}$ College of Agriculture, Ibaraki University, Japan, 3-21-1, Chuuo, Ami, Inashiki, \\ Ibaraki, Japan 300-0393 \\ Correspoding Author: mirwan_ushada@ugm.ac.id; mirwan@tip-ugm.org*
}

\begin{abstract}
The term of indigenous knowledge refers to specific local knowledge in consumer/user which should be incorporated by agro-industry to compete in a globalized worlds. This research highlighted Kansei Engineering as a potential approach to quantify indigenous knowledge in agro-industrial technology. The research objectives were: 1) To review the quantification tools of indigenous knowledges in agro-industrial technology using Kansei Engineering; 2) To characterize indigenous knowledges in Indonesian agro-industry. Case study was demonstrated in Indonesian food product, services and ergonomic technology. Quantification was characterized using widely developed quantification tools for indigenous knowledges. The research results concluded some indigenous knowledges which could be incorporated in indigenous knowledge-based innovations.
\end{abstract}

Keywords: Agro-industry, Ergonomic technology, Product, Services, Technical parameters

\section{INTRODUCTION}

The ASEAN policy blueprint for SMEs Development (APBSD) 2004-2014 has described the framework to support SMEsbased Agro-industry development (Anonym, 2008). One of its objectives is enhancing the competitiveness and dynamism of ASEAN industry by facilitating their access to agroindustrial market, human resource development, skills, finance, and information technology (Anonym, 2008).

Agro-industry is a fundamental typeindustry to challenge the ASEAN Economic Community (AEC). AEC challenged agroindustry to increase the performance and professional qualifications. Globalization in economy and information has been forcing agro-industry to pursue continuous innovation. Innovation in agro-industry should be supported by exploring more indigenous knowledges in agro-industrial technology.

The term of indigenous knowledge refers to specific local knowledge in consumer/user which should be incorporated by agro-industry to compete in a globalized worlds. Ushada et al. (2010) stated that knowledge is a statement of knowledge that a consumer knows, or could know, or might know about a product.

Some researches were pursued related to indigenous knowledges in Asian Country as beach seine fisheries management in Srilanka (Ashoka Deepananda et al., 2015) and medicinal plants in Pakistan (Ishtiaq et al., 2015). However, none of them were related to indigenous knowledges in agro-industrial technology.

Kansei Engineering is a potential method to quantify indigenous knowledges. It can be used to assist human identifying the needs, preference or achieving satisfaction for work system/product (Nagamachi, 1995). Ushada and Murase (2009) has utilized Kansei Engineering to quantify prior knowledge to affective design of greening material.

This research highlighted Kansei Engineering as an potential approach to quantify indigenous knowledge in agroindustrial technology. The research objectives are: 1) To review the quantification tools of indigenous knowledges in agro-industrial technology using Kansei Engineering; 2) To characterize indigenous knowledges in Indonesian agro-industry. 


\section{MATERIALS AND METHODS}

The indigenous knowledges were quantified based on the secondary data of case studies in Indonesian food product, services and ergonomic technology. Four scopes for product design and development were evaluated as greening materials (Ushada and Murase, 2009; Ushada et al., 2012), human preference reasoning (Ushada and Murase, 2008), nata de cassava (Sari, 2011) and pickle packaging (Sari, 2015).

Subsequently, four scopes for services design and development were evaluated as food outlet (Hidayah, 2011), layout of supermarket (Rusmawan, 2013), in-flight menu (Hidayat, 2015) and food menu (Fiantini, 2013).

Finally, four scopes for ergonomics technology were evaluated as portable dining table and chairs for the beach (Restantin et al., 2012), job satisfaction (Risqi et al., 2015), capacity constrained worker (Zuriwiatma et al., 2014) and KESAN (Kansei Engineering-based Sensor for Agro-industry) (Ushada et al., 2015a;2015b).

\section{RESULTS}

The review analysis were pursued to area of product, service and ergonomic technology, as defined in Tables 1, 2 and 3 respectively:

Table 1. Quantification of indigenous knowledges in product design and development

\begin{tabular}{|c|c|c|c|}
\hline Scope & \begin{tabular}{|l} 
Indigenous knowledges \\
\end{tabular} & Quantification tools & Technical parameters \\
\hline $\begin{array}{l}\text { Greening } \\
\text { Material } \\
\text { (Ushada et al., } \\
\text { 2009; Ushada } \\
\text { et al., 2012) }\end{array}$ & $\begin{array}{l}\text { - Surrounding season such as } \\
\text { autumn, summer, fall and } \\
\text { winter, influenced the } \\
\text { consumer preference } \\
\text { - Water content influenced the } \\
\text { surface attractiveness of } \\
\text { greening material }\end{array}$ & Bird swarm algorithm & $\begin{array}{l}\text { - Japanese prefers wet } \\
\text { greening material } \\
\text { and Indonesian } \\
\text { prefer semi dry } \\
\text { - Affective design }\end{array}$ \\
\hline $\begin{array}{l}\text { Human } \\
\text { Preference } \\
\text { Reasoning } \\
\text { (Ushada and } \\
\text { Murase, 2008) }\end{array}$ & $\begin{array}{l}\text { - Consumer decision to buy a } \\
\text { product was influenced by } \\
\text { some conditional reason as } \\
\text { agreement, prior knowledge } \\
\text { and familiarity } \\
\text { - Consumer knew that } \\
\text { customized product is } \\
\text { preferable to match his or } \\
\text { her unique preferences. }\end{array}$ & $\begin{array}{l}\text { Conditional } \\
\text { probability co- } \\
\text { occurrences matrix of } \\
\text { texture analysis }\end{array}$ & $\begin{array}{l}\text { These reasoning can be } \\
\text { extracted to statitical } \\
\text { features of grey level } \\
\text { co-occurrences } \\
\text { matrixes as Energy, } \\
\text { Contrast, Local } \\
\text { Homogeneity, } \\
\text { Correlation and Entropy }\end{array}$ \\
\hline $\begin{array}{lr}\text { Nata } & \text { de } \\
\text { cassava } & \text { (Sari, } \\
\text { 2011) } & \end{array}$ & $\begin{array}{l}\text { - Consumer did not know the } \\
\text { difference between nata de } \\
\text { cassava and nata de coco } \\
\text { - Price of nata de cassava was } \\
\text { cheaper than nata de coco }\end{array}$ & $\begin{array}{l}\text { Kansei words and } \\
\text { value engineering }\end{array}$ & $\begin{array}{l}\text { Consumer knows the } \\
\text { attribute differences } \\
\text { between nata de } \\
\text { cassava and nata de } \\
\text { coco so it can support } \\
\text { nata de cassava as } \\
\text { substituted product }\end{array}$ \\
\hline $\begin{array}{l}\text { Pickle } \\
\text { packaging } \\
\text { (Sari, 2015) }\end{array}$ & 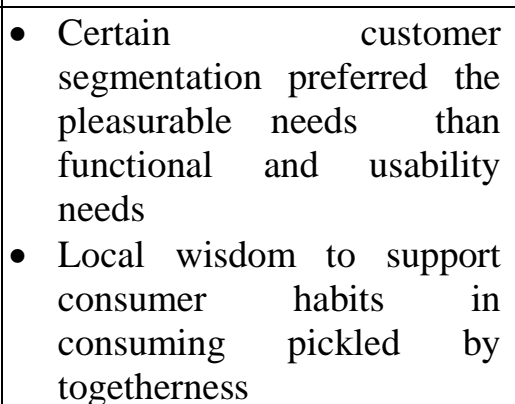 & $\begin{array}{l}\text { Kansei rords, } \\
\text { Principal Component } \\
\text { Analysis (PCA), } \\
\text { Quantification theory } \\
\text { Type 1, Interval Type } \\
2 \text { Fuzzy Sets (IT2FS) }\end{array}$ & $\begin{array}{l}\text { An affective design for } \\
\text { pickle packaging of } \\
\text { 'standard-attractive' } \\
\text { image }\end{array}$ \\
\hline
\end{tabular}


Table 2. Quantification of indigenous knowledges in service design and development

\begin{tabular}{|c|c|c|c|}
\hline Scope & Indigenous knowledges & Quantification tools & Technical parameters \\
\hline $\begin{array}{l}\text { Food outlet } \\
\text { (Hidayah, } \\
\text { 2011) }\end{array}$ & $\begin{array}{l}\text { - Consumer preferred the } \\
\text { seller who can speak the } \\
\text { local languange } \\
\text { - Consumer preferred to see } \\
\text { clearly the cooking processs } \\
\text { while communicating with } \\
\text { the seller }\end{array}$ & $\begin{array}{lr}\text { Kansei } & \text { words and } \\
\text { Quality } & \text { function } \\
\text { deployment } & \end{array}$ & $\begin{array}{l}\text { - Capability of seller } \\
\text { to communicate } \\
\text { using the local } \\
\text { javanese languange } \\
\text { - Outlet design using } \\
\text { transparancy glasses }\end{array}$ \\
\hline $\begin{array}{l}\text { Layout of } \\
\text { supermarket } \\
\text { (Rusmawan, } \\
\text { 2013) }\end{array}$ & $\begin{array}{l}\text { - Straightly-typed of } \\
\text { consumer who want to } \\
\text { directly buy the preferred } \\
\text { products } \\
\text { - Comfort-typed of consumer } \\
\text { who like to enjoy spending } \\
\text { longer shooping time }\end{array}$ & $\begin{array}{l}\text { Quantification Theory } \\
\text { Type } 1\end{array}$ & $\begin{array}{l}\text { Design of layout which } \\
\text { can be adjusted based } \\
\text { on consumer } \\
\text { preference }\end{array}$ \\
\hline $\begin{array}{l}\text { In-flight meal } \\
\text { services } \\
\text { (Hidayat, } \\
\text { 2015) }\end{array}$ & $\begin{array}{ll}\text { - } & \text { Consumer segmentation } \\
& \text { using social media } \\
\text { - } & \text { Variety seeking } \\
\text { - } & \text { Neophobia } \\
\text { - } & \text { Variety seeking selective }\end{array}$ & $\begin{array}{l}\text { Pillar K-mining } \\
\text { Quantification Theory } \\
\text { Type } 1\end{array}$ & $\begin{array}{l}\text { Various types of service } \\
\text { design based on } \\
\text { consumer segmentation }\end{array}$ \\
\hline $\begin{array}{l}\text { Food menu } \\
\text { (Fiantini, } \\
\text { 2013) }\end{array}$ & $\begin{array}{l}\text { - Consumer knew the wide- } \\
\text { range menu consist of } \\
\text { combination of selective } \\
\text { food and drink }\end{array}$ & $\begin{array}{l}\text { Quantification Theory } \\
\text { Type } 1\end{array}$ & $\begin{array}{l}\text { Various types of food } \\
\text { menu based on image }\end{array}$ \\
\hline
\end{tabular}

Table 3. Quantification of indigenous knowledges in ergonomic technology

\begin{tabular}{|c|c|c|c|}
\hline Scope & \begin{tabular}{|l|} 
Indigenous knowledges \\
\end{tabular} & $\begin{array}{l}\text { Quantification } \\
\text { tools }\end{array}$ & \begin{tabular}{|l|} 
Technical parameters \\
\end{tabular} \\
\hline $\begin{array}{l}\text { Portable } \\
\text { dining table } \\
\text { and chairs for } \\
\text { the beach } \\
\text { (Restantin, } \\
\text { 2012) }\end{array}$ & $\begin{array}{l}\text { - Consumer knew that the } \\
\text { beach is surrounded by open } \\
\text { space of pine trees } \\
\text { - Consumer preferred } \\
\text { "Lesehan" (Seat at the sand) }\end{array}$ & $\begin{array}{lr}\text { Integration } & \text { of } \\
\text { Ergonomic, Value } \\
\text { Engineering and } \\
\text { Kansei Engineering }\end{array}$ & $\begin{array}{l}\begin{array}{l}\text { Protoype of semi- } \\
\text { customized } \\
\text { dining table and chairs }\end{array} \\
\text { portable }\end{array}$ \\
\hline $\begin{array}{l}\text { Job } \\
\text { satisfaction } \\
\text { (Risqi et al., } \\
\text { 2015) }\end{array}$ & $\begin{array}{l}\text { Worker preferred more job sati } \\
\text { sfaction and less workload }\end{array}$ & Linear regression & $\begin{array}{l}\text { Worker performance was } \\
\text { affected by job satisfacti } \\
\text { on and workload by } 44 \text {. } \\
1 \%\end{array}$ \\
\hline $\begin{array}{l}\text { Capacity } \\
\text { Constrained } \\
\text { Worker } \\
\text { (Zuriwiatma } \\
\text { et al., 2014) }\end{array}$ & $\begin{array}{l}\text { Workers had overwork more } \\
\text { than their actual capacity to } \\
\text { achieve the production target } \\
\text { and wages }\end{array}$ & Buffer management & $\begin{array}{l}\text { Workload improvement } \\
\text { in the work system }\end{array}$ \\
\hline $\begin{array}{l}\text { Sensor } \\
\text { (Ushada et al., } \\
\text { 2015a; } \\
\text { Ushada et al., } \\
\text { 2015b) }\end{array}$ & \begin{tabular}{|l}
\multicolumn{3}{l}{ Worker performance can be } \\
classified to Capacity \\
constrained worker (Over \\
work), Over capacity worker \\
(Underwork) and normal
\end{tabular} & $\begin{array}{l}\text { Artificial neural } \\
\text { network and arduino }\end{array}$ & $\begin{array}{l}\text { KESAN } \\
\text { Engineering-based } \\
\text { Sensor for Agro- } \\
\text { industry) }\end{array}$ \\
\hline
\end{tabular}




\section{DISCUSSIONS}

Table 1 indicated some research related to product design and development. Most of indigeous knowledges were characterized by attributes consumer preference since product performance is tangible. The external factors as environment and price strongly influenced the consumer decision to buy product. The quantification tools varied from artificial intelligence as bird swarm, statistical patterns as conditional probability, systematical approach as value engineering and hybrid method for pickle packaging.

Table 2 indicated some research related to service design and development. Most of indigenous knowledges were characterized by complex consumer segmentation since service performance is intangible. Most of the quantification tools are related to statistical aprroach and hybrid method.

Table 3 indicated some research related to application of ergonomic technology. Most of indigenous knowledges are characterized by the work system. The quantification tool is widely developed from statistical, theory of constraint and sensor.

\section{CONCLUSIONS}

This paper has reviewed the application of Kansei Engineering to quantify the indigenous knowledges in agro-industrial technology. Up to date, Kansei Engineering indicated the promising progress to quantify indigenous knowledges in agro-industrial technology. Indigenous knowledges can be characterized to the wide range-type of product, services and ergonomic technology. Besides, there were widely developed available quantification tools for indigenous knowledges. These knowledges could be incorporated to support indigenous knowledge-based innovations in agro-industry.

This review suggested the futher amenities of Kansei Engineering to solve the macro problems as corporate social responsibility and health insurance in agroindustry.

\section{ACKNOWLEDGEMENT}

We would like to express our sincere gratitude and acknowledge the Financial Support from Directorate of Human Resources-Universitas Gadjah Mada (No: 4903/SDM/PSDM/2015). Some of the research data were based on Research Grants from Directorate General for Higher Education, Indonesian Ministry of Education and Culture for 2014 (No.: LPPM-UGM/1008/LIT/2014) and 2015 (No.: 310/LPPM/2015) International Research Collaboration and Scientific Publication (Penelitian Kompetitif Nasional: Kerjasama Luar Negeri dan Publikasi Internasional) -Universitas Gadjah Mada.

\section{REFERENCES}

Anonym.2008. ASEAN Economic Community Blueprint, ASEAN Secretariat, Jakarta, ISBN 978-979-3496-77-1

Ashoka Deepananda, K. H. M., U. S. Amarasingje, U. K. Jayasinghe-Mudalige. 2015. Indigenous Knowledge in the Beach Seine Fisheries in SriLanka:An Indispensable Factor in Community-based Fisheries Management. Marine Policy. 57(2015) 69-77

Fiantini, A. 2013. Determination Of Package Menu Based On Product Image With Kansei Engineering Approach (Case Study At Goat Milk Caffe Northern Ringroad , Yogyakarta) (In Bahasa Indonesia). Undergraduate thesis, Department of Agro-industrial Technology. Universitas Gadjah Mada.

Hidayah, U.N. 2011. Improvement of Service System in Franchise Outlet of Snack Using Quality Function Deployment (QFD) Based on Kansei Engineering Concept (Case Study at Tela Tela Outlet, CV. Effa Indoboga, Yogyakarta) (In Bahasa Indonesia). Undergraduate thesis, Department of Agro-industrial Technology. Universitas Gadjah Mada.

Hidayat. H. H. 2015. Pleasurable In-flight meal Services Design based on Passengger's Personality Traits using Hybrid Kansei Engineering. Thesis of Master Degree. Department of Agro-industrial Technology, Institut Pertanian Bogor

Ishtiaq, M., A. Mahmood, M. Maqbool. 2015. Indigenous Knowledge of Medicinal Plants from Sudhanoti District (AJK), Pakistan. Journal of Ethnopharmacology. 168 (2015): 201-207

Nagamachi, M. 1995. Kansei Engineering: a New Ergonomic Consumer-oriented Technology for Product Development, 
International Journal of Industrial Ergonomics, Vol. 15, No. 1,pp.3-11.

Risqi, R. O, M. Ushada and W. Supartono. 2015. Analysis of Job Satisfaction and Its Influence to the Worker Performance Using Kansei Engineering OF XYZ Company (In Bahasa Indonesia), Agritech, Vol.35 (1), 2015 pp. 133-139

Restantin, N., M. Ushada and M. Ainuri. 2012. Desain Prototipe Meja dan Kursi Pantai Portabel dengan Integrasi Pendekatan Ergonomi, Value Engineering dan Kansei Engineering. Universitas Kristen Petra Surabaya/Jurnal Teknik Industri Vol. 14. No.1, Juni 2012, 53-62.

Rusmawan, E. 2013. Determination of Department Store Design based on Shopping Image and Kansei Engineering Approach (Case study at Prima Swalayan, Srandakan) (In Bahasa Indonesia). Undergraduate thesis, Department of Agro-industrial Technology. Universitas Gadjah Mada.

Sari, Novi P. 2011. Development of Packaged Nata De Cassava Products With Value Engineering Method Based on Kansei Word (In Bahasa Indonesia). Undergraduate thesis, Department of Agro-industrial Technology. Universitas Gadjah Mada.

Sari, N. P. 2015. An Affective Design for Pickle Packaging. Thesis of Master Degree. Department of Agro-industrial Technology, Institut Pertanian Bogor

Ushada, M. and H. Murase. 2009. Design of Customisable Greening Material using Swarm Modelling. Biosystems Engineering. 104(2): 169-183

Ushada, M. 2010. Bird Swarm Algorithm in Kansei Engineering to derive Consumer Satisfaction. Doctoral Dissertation. Graduate School of Life and Environmental Sciences, Osaka Prefecture University, Japan.

Ushada, M., A. Wicaksono, H., Murase. 2012. Design of Moss Greening Material for Merapi Disaster Prone Area using Kansei Engineering. Engineering in Agriculture, Environment and Food. 5(4): 140-145, 2012.

Ushada, M, T. Okayama, A. Suyantohadi, N., Khuriyati, H. Murase. 2015a. Kansei Engineering-based Artificial Neural Network Model to Evaluate Worker
Performance in Small-Medium Scale Food Production System. International Journal of Industrial and Systems Engineering. Status: In Press

Ushada, M., T. Okayama and H. Murase 2015b. Development of Kansei engineering-based Watchdog Model to Assess Worker Capacity in Indonesian Small-medium Food Industry',Engineering in Agriculture, Environment and Food, in press, corrected proof, 7 May 2015[online] http://www.sciencedirect.com/science/artic le/pii/S1881836615000245.

Zuriwiatma, M, M. Ushada and G. T. Mulyati. 2014. Analysis of Capacity Constrained Worker Using Time Study, Heart Rate and Profile of Mood States (Case Study of Tempe Industry "Muchlar" Kasihan Bantul) (In Bahasa Indonesia), Agritech, 34 (3), 2014 